\title{
DEVELOPMENT OF CASH WAQF BENEFITS SYNERGY FOUNDATION IN THE ECONOMIC EMPOWERMENT OF THE UMMAT
}

\author{
M. Rachmat Effendi \\ Faculty of Da'wah, Bandung Islamic University \\ muhammadrahmateffendi@gmail.com
}

\begin{abstract}
This paper discusses the development of cash waqf benefits which is directed at empowering the community's economy carried out by the synergy foundation in West Java. Cash waqf as one of the shari'ah financial instruments should be able to provide added value usefulness and a multifier effect in reviving the community's economy. The aim is to map the quality of institutions in managing the benefits of cash waqf for the economic empowerment of the people. The approach used is case studies with qualitative methods, the data were analyzed descriptively with a phenomenological naturalistic paradigm which emphasizes the nature of social reality and studies what appears in society. The results obtained in the field Sinergi Foundation have carried out professional, transparent and accountable, financial management using the accounting standard for zakat PSAK 109. The financial reports are audited by an independent public accountant and the results are Unqualified (WTP).
\end{abstract}

Keywords: development, cash waqf, economic empowerment

\section{Introduction}

\section{Background Problems}

Waqf is one of the financial instruments used by the Prophet Muhammad during his leadership. The development of waqf at that time showed a tremendous effect on improving the welfare of the people. Waqf affects the economic level of the people Syekh et al. (2017). can help reduce poverty (Sadeq, 2002; Atan \& Johari, 2017); can increase the human development index (Mohamad et al., 2014); can finance the needs of the community Ambrose at al (2018), and can improve socio-economic development. (Ridwan, 2018). Even during the Mamluk and Ottoman Turks, cash waqf developed well. In modern times, the waqf movement has received a lot of attention from Muslim scholars, and Islamic economists. Cash waqf became the main topic of intensive discussion and research. As in Turkey, Syria, Palestine, Iraq, Sudan, Morocco, Saudi Arabia, including in Indonesia, because the potential for waqf is relatively high. If it is managed professionally and proportionally, it will have a positive impact on improving the economy of the people (Abdurrohman Kasdi, 2018).

Research on waqf conducted by previous researchers in relation to the economic empowerment of the ummah has been widely carried out. Some issues that have

Received: 2020-11-09 | Reviced: 2020-12-13 | Accepted: 2020-12-22

Indexed : Sinta, DOAJ, Garuda, Crossref, Google Scholar | DOI: https://doi.org/10.29313/amwaluna.v5i1.6916 
been identified are the issue of utilization of waqf for micro, small and medium enterprises through the takafful models approach Mikail et al (2017). Waqf Savings Program (TWI), through the property sector by Dompet Dhuafa (Siswanto \& Suprapto, 2014) has proven the contribution of waqf to the society. Other issues include eucational empowerment health care (Usman, 2014) and overall ineffectiveness of waqf management (Abdul Mubaraq, 2018) including the level of nadzir's professionalism in managing productive waqf assets hence the needs of organisational restructure (Nurul Azma et al. 2017) to increase accountablity of waqf institutions, Hisham et al. (2018). This research is different from previous research, the urgency of this research is directed at the institutional quality of cash waqf management which is associated with the provision of benefits for the economic empowerment of the ummah.

This paper discusses the management of cash waqf which is directed at community economic empowerment by the Sinergi Foundation in West Java. Given the economic life of the people of West Java during the Covid-19 pandemic, it has shown a serious decline and is even threatened with bankruptcy. Therefore, through effective and efficient management of cash waqf as one of the shari'ah financial instruments it is hoped that it can provide added value, usefulness and a multifier effect in reviving the community's economy, especially for economic actors affected by Covid 19. The problem is how to manage cash waqf effectively and efficiently so that it can provide benefits for the economic empowerment of the people. In turn, this study can contribute to the scientific development of Islamic institutional managers (zakat, infaq shodaqoh and waqf) in particular and syari'ah financial institutions in general.

\section{State of The Arts}

\section{The Cash Waqf}

In language Waqf means stop or stand (waqafa/yaqifu /waqfan) and in terms of syara 'the definition of waqf according to Muhammad Ibn Ismail in Subulus Salam is to hold the property that might be taken benefit without spending or damaging the object (ainnya) and used for good. So waqf objects cannot be owned privately or individually (mahjur mahjur), waqf objects are property of Allah SWT which is classified as public property (public interest) with specific goals (Huda, 2012; Huda \& Heykal, 2010) Waqf development in the form of money, known as cash waqf, has been done for a long time. Even in Islamic history, cash waqf has been practiced since the second century Hijriyah. As in the hadith narrated by Imam Bukhari, that Az-Zuhri (died 124), a prominent scholar and founder of tadwin al-hadith, gave his fatwa to waqf with Dinar and Dirham so that it could be used as a means of development, preaching, social and education. Muslims. The way this is done is to make the money as business capital (productive capital) and then channel the profits as Waqf. The ability of cash waqf was also stated by the Hanafi and Maliki Schools. Even some of the scholars of the Shafi'i School also allow cash waqf as called Al-Mawardy (Chamidah, U: 2008).

This opinion was quoted by the MUI Fatwa Commission (2002) in legitimizing cash waqf. In Indonesia, since the issuance of the 
MUI fatwa on May 11, 2002, the issue of whether or not money is allowed is no longer a problem. The contents of the MUI fatwa are as follows: (1) Money waqf (cash waqf al-nuqud) is waqf that is carried out by a person, group of people, institution, or legal entity in the form of master money, (2) Included in the definition of money are letters valuable, (3) Waqf the legal money is jawaz (allowed), (4) Waqf money can only be distributed and used for things that are permitted in syar'iy. The sustainability of the waqf principal value of money must be guaranteed, not to be sold, gifted and / or inherited. (Departemen Agama, 2007) .

The development of cash waqf has strategic economic value. With the development of cash waqf, a number of advantages will be obtained, among them. First, the amount of waqf money can vary so that someone who has limited funds can start giving his waqf funds without having to wait to become a rich person or landlord first, so that the cash waqf program will make it easier for the waqf or waqif giver to do the waqf. Second, through Waqf money, Waqf assets in the form of empty land can begin to be utilized by building buildings or being processed for agricultural land. Third, cash waqf funds also help some Islamic educational institutions whose cash flow has fluctuated in paying their academicians. Fourth, in turn, Muslims can be more independent in developing the world of education without having to rely on the State's education budget which is increasingly limited. Fifth, cash waqf funds can empower small businesses that are still dominant in this country. The funds collected can be distributed to these entrepreneurs and the profit sharing is used for social purposes.
Sixth, cash Waqf funds can help the development of Islamic banks, especially Islamic BPRs. The advantages of Waqf funds, apart from being perpetual or longterm, Waqf funds are the cheapest funds that should be the target of Sharia banks.

\section{Productive Waqf Asset Management}

The scope of waqf asset management includes several planning stages including (1) asset inventory, (2) legal audit, (3) asset valuation, then asset utilization stages such as (4) Asset Optimization by utilizing assets for operational activities directly or in cooperation with parties third, and finally the evaluation and monitoring stages, namely (5) Supervision and Control including assessing asset performance, updating asset data, adding or selling assets, maintaining assets, and settling all obligations related to the existence of assets. With good asset management, asset utilization is expected to be more effective and efficient so that the existence of assets provides the best value for all parties (Siregar, 2004).

Waqf asset management is the process of accumulating productive capital and assets through current investments for future benefits, so that waqf management has a sacrifice of consumption opportunities at the present time for the purpose of providing better income and services for future generations, because the purpose of the waqf project is to optimize the function of waqf property as infrastructure to improve the quality of life of human resources.

\section{Community Economic Empowerment}

Whether we realize it or not, national poverty is still a very crucial problem. With the presence of an institution that is 
concerned about managing Waqf (cash), the contribution in overcoming the problems of poverty and ignorance that plague the nation will be more helpful and within a certain period the benefits will be more significant.

When examined in terms of the goals and contributions that the money waqf institution can provide, the existence of money waqf (in Indonesia) becomes very crucial. At least there are several things that lead to the importance of empowering cash waqf in Indonesia: First, the economic crisis leaves many problems, the number of poor people increases, dependence on debt and foreign assistance. Second, there is a high gap between the rich and the poor. Third, Indonesia has the largest Muslim population, so Waqf has great potential to be developed. Fourth, a number of disasters have resulted in the procurement of public goods.

\section{Methodology}

This type of research is a case study. This research was conducted at the Synergy Foundation as one of the foundations that manages waqf assets, especially cash waqf in West Java and other places related to the empowerment of the ummah. Sinergi Foundation whose full name is Yayasan Semai Sinergi Ummat (WAKAF PRO99), located at Jl. Sidomukti No. 99 H Bandung 40123 Tel. 022-6032281 Fax. 022-6120130, a foundation that manages waqf assets based on law and registered with the Indonesian Waqf Board with No. Registration 3.3.00056. These types of collected data are observational data, interview data, and documentary data. (

Research Approach and Data Collection Method.
This study used a qualitative approach, the data were analyzed descriptively (Moleong, 2009) with a phenomenological naturalistic paradigm which emphasizes the nature of social reality and studies what appears in society. The aim is to interpret and explain the meaning contained in various Synergy Foundation activities in the economic empowerment of the ummah.

\section{Data Analysis}

The data obtained in this study were analyzed qualitatively through the following steps: First, the author applies content analysis, in this case the researcher analyzes communication data or phenomena (Muhajir, 1990) to make objective and systematic conclusions by identifying specific characteristics of messages or data (Holsti, 1969). Second, the researcher uses synthesis analysis, by examining as carefully as possible the thesis that develops the economic empowerment efforts undertaken by the West Java Synergy Foundation, in accordance with the objectives of this study (Van Laer, 1956).

\section{Discussion}

Based on the findings in the field, the development of the benefits of cash waqf which is managed by the West Java Synergy Foundation in empowering the economy of the Ummah is as follows:

\section{Profile}

SINERGI FOUNDATION (SF) is a publicly owned independent institution that is concerned with encouraging the development of creativity and innovation of Social-Empowerment based on Productive Waqf and ZIS (Zakat, Infaq-Alms). With 
synergy between all care elements to increase capacity and expand the scope of service, $\mathrm{SF}$ is committed to paving a familiar path by utilizing local resources to realize an independent, productive, and character society.

\section{Logo History}

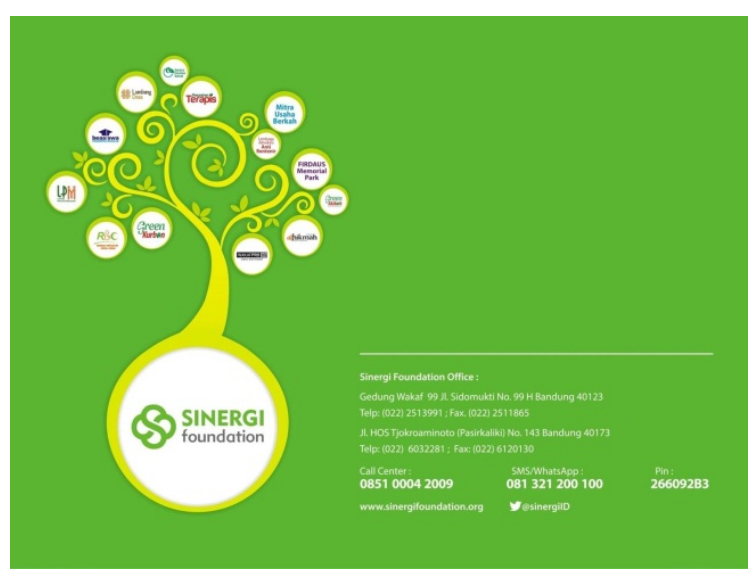

Picture1 Logo Sinergi Foundation

Source: Sinergi Foundation financial reports 2020

Synergy is a word that has a million meanings. It has now become part of our daily life in interacting with others. Togetherness, partnership, cooperation, merging, caring, and much more. Therefore, the combination of two 'S' letters, taken from the first letter of the word Sinergi, feels right to be used as a visual identity (logo), a marker for the Sinergi Foundation. The letter'S,' which is inseparable, denotes a shared commitment to building and reaching goals firmly and in harmony.

The affirmation then strengthens this visual identity (logo) that SINERGI FOUNDATION is an independent publicly-owned institution concerned with encouraging creativity and social innovation -Empowering based on Productive Waqf and ZIS. With synergy between all care elements, it can increase the capacity and expand the scope of service. SF is committed to paving a familiar path by utilizing local resources to realize an independent, productive, and character society, then described in a Corporate Slogan (tagline) \#BerbagiBersinergi (sharing benefits).

\section{History}

On October 14, 2002, the Semai Synergy Umat Foundation's embryo was found by Prof. Dr. KH. Miftah Faridl, who is also the Chairman of the Board of Trustees. He was also signing the Foundation deed as a member of the Board of Trustees, $\mathrm{H}$. Rachmat Badruddin (Entrepreneur / Chair of the Indonesian Tea Council), H. Achmad Noe' man H. Erie Sudewo (Social Entrepreneur / Founder of Dompet Dhuafa Republika). The founding of the Foundation was witnessed directly in front of the Notary Evy Hybridawati Wargahadibrata, SH.

In its work in society, the Semai Synergy Umat Foundation's embryo has led to various inspirational empowerment program activities in the fields of health, education, economy, and charity. That is reflected in, among others, the birth of Free Maternity Homes (RBC), Community Service Institutions (LPM), SF Rescue, Rentenir Free Synergy and Advocacy, Ternakita, Nation Leaders Scholarships (BPB), my teacher, Schools for All, as well as Islamic Boarding Schools. Therapist. During its development, the Productive Waqf Institution (WakafPro 99), Alhikmah Tabloid, Green Akikah, Synergy Training Center, and several others were born.

Over time the development of institutions, which is directly proportional to the complexity of the people's problems that have emerged, demands a change in the 
institutional format as a form of settlement. Therefore, at the Official Meeting of the Board of Trustees on February 17, 2011, the Semai Sinergi Umat Foundation's embryo was turned into the Semai Sinergi Umat Foundation (Sinergi Foundation). These changes were formally legalized in Notary Deed Number 24, dated February 17, 2011, made by Notary Evi Hibridawaty, SH, and decided by the Decree of the Minister of Law and Human Rights of the Republic of Indonesia Number: AHU - 5622.AH.01.05. 2011 concerning Amendments to the Articles of Association of the Foundation Articles 1 and 5, namely the Change of Name to the Semai Sinergi Umat Foundation or Sinergi Foundation.

Synergy Foundation was confirmed as Nazhir Waqf, according to the BWI Decree (Indonesian Waqf Board) Certificate of Registration Nadzir Registration Number: 3.3.00056. as well as an Amil Zakat Institution by the Decree of the Minister of Religion DJ.III / 564 of 2016.

\section{Vision}

The developer of Social Creativity and Innovation - Empowerment Based on Productive Waqf and ZIS.

\section{Mission}

Encourage the development of creativity and social innovation - empowerment based on productive waqf and ZIS.

- Build synergies between elements of care in order to increase capacity and expand the reach of community service.

- Pave a familiar path by utilizing local resources to realize an independent, productive, and character society.

\section{Purpose}

- The creative development and social innovation - empowerment based on productive waqf and ZIS carried out.

- The realization of synergy between elements of care to increase and expand the capacity of solemn / community service.

- The realization of society who independent, productive, and character through local resources.

\section{Cash Waqf Management}

Sinergi Foundation is an institution that focuses on managing public funds, namely Zakat, Infak Alms, and Waqf funds (ZISWAF). Has been active since 2002, although it was still called the Dompet Dhuafa Bandung Foundation. However, as a legal waqf Nazdir, it started in 2011 based on SK BWI (Indonesian Waqf Board) Certificate of Registration Nadzir Registration Number: 3.3.00056.

The decree refers to the Synergy Foundation to manage fund waqf of society through three processes, namely collection management, financial management, and utilization of endowment funds.

\section{Collection of Waqf funds}

The collection of waqf funds has been carried out on an ongoing basis from 2011 to the present. The collection process carried out with various approaches, including:

1. Waqf education. Education is the necessary capital in collecting waqf because it determines someone to deposit or distribute waqf funds. SF carries out educating the community on waqf externally through various activity programs, for example, the waqf study program in mosques or majlis tackle. 
Then the donor gathering, where the contents convey a variety of information about waqf from the aspect of sharia or waqf utilization programs. However, currently, the focus of education is carried out through social media, especially since the Covid 19 outbreak.

2. Waqf fundraising. The collection of funds from muwakif is a further step in the educational process. People who already understand and touched by their faith to set aside part of their assets as waqf must respond quickly. The serv $n$ accumulation of endowments performed SF includes transfer waqf, endowments shuttle, and station service donations waqf. Siti Haura (Chief Operational Officer) said that for the Bandung area, most of these services are waqf transfer, pick-up of waqf, and donation services at the office. Last three years, the collection of waqf has increased by $103 \%$ from $2017-2018$, but from 2018 - 2019, there has been a decrease of $-69 \%$.

Table 1 The collection of funds from muwakif

\begin{tabular}{|l|l|}
\hline \multicolumn{1}{|c|}{ Year } & Collection Value \\
\hline 2017 & $2,834,858,058$ \\
\hline 2018 & $5,758,101,697$ \\
\hline 2019 & $1,732,195,053$ \\
\hline
\end{tabular}

Source: Sinergi Foundation financial reports 2020

Based on the interview results, the significant increase in 2018 was due to the massive publication of 3 mon In Chileumental new programs, namely the Healthy Home for Mother and Child Waqf in the afternoon, the Al-Fatih Kutab School In Chile and the Tahfidz Islamic Boarding School in Lembang. The three programs had a significant impact on increasing the collection by up to $103 \%$. The results of simple research conducted by Dompet Dhuafa show that the highest percentage of reasons for waqf is an exciting program. Thus, it is natural that in 2018 the Synergy Foundation experienced a significant increase in waqf funds acquisition.

Meanwhile, the massive decline in 2019 was influenced because the three programs' progress or development in 2018 did not yet exist, so donors were not encouraged to make donations. This condition resulted in a decrease in the acquisition of waqf by $-69 \%$.

\section{Management Financial Endowments}

Financial management is conduct in a professional, with transparency and accountability. The process is carried out in the financial management of funds endowments using accounting standards charity that is PSAK 109. It was done because Synergy Foundation managed the funds' value is funding Zakat and donation in which the standard must be used for the fund is the Statement of Financial Accounting Standards (PSAK) 109 concerning Zakat and Infaq.

Every year the financial report is audited by an independent public accountant, where the results obtained so far have an unqualified opinion. That shows that the process of managing waqf funds has been done correctly and adequately. Besides, the WTP opinion illustrates the form of transparent and accountable financial management. 
Table 2 Receipt and use of waqf funds for the last three years

\begin{tabular}{|c|c|c|}
\hline $\begin{array}{l}\mathbf{Y E} \\
\mathbf{A R}\end{array}$ & COLLECTION & USE \\
\hline $\begin{array}{l}201 \\
7\end{array}$ & $\begin{array}{ll} & 2,834, \\
858,058 & \end{array}$ & $23,650^{1,678,0}$ \\
\hline $\begin{array}{l}201 \\
8\end{array}$ & $\begin{array}{ll} & 5,758, \\
101,697 & \end{array}$ & $73,250^{4,625,9}$ \\
\hline $\begin{array}{l}201 \\
9\end{array}$ & 1,732, & $\begin{array}{l}1_{18,074}^{12,709,7} \\
\end{array}$ \\
\hline
\end{tabular}

\section{Waqf fund utilization}

The use of cash and waqf collected by the Sinergi Foundation for the 2017-2019 period is divided into the following usage categories:

1. The use and waqf for social, education, and health activities, namely for the Firdaus Memorial Park program, namely Muslim burials where the grave land is purchased from waqf funds and was intended for the community, both waqf or not. Alfatih Kutab School and Maternal and Child Waqf Healthy Homes. In the last three years for the social, health, and education sectors, total usage was IDR 3,721,443,060.

2. The use of productive waqf funds is cash use and waqf for business activities, where $90 \%$ of the business proceeds are used for social activities and community empowerment. Then $10 \%$ for program operations. Some of the waqf funds businesses include Fashion Stores (Vamoosh and Yesamalika), Culinary (Ampera Restaurant, Hai Coffe, Cuangki Serayu, and Ayam Geprek Pangeran), Housing Properties, and Herbs. Total funds were rolling for the productive endowments business amounting to $\mathrm{Rp}$
15,292,271,914 (fifteen billion two hundred and ninety-two million two hundred seventy-one thousand nine hundred and fourteen rupiahs).

Based on research findings, the community economic empowerment program is called the Waqf Integrated Farming (WIF) program. The goal is to encourage waqfbased community economic activities. The cooperation system used is the "mudlaba" system. The mudloroba system is explained by Surahman (2020) by referring to the Sharia Economic Law Compilation that: "Mudhâraba is cooperation between fund owners or investors and capital managers to conduct certain businesses with profit sharing based on ratio. Therefore, what is meant by mudhârabah contract is a business cooperation agreement between two parties where the first party (shâhib al-mâl) provides all (100\%) capital, while the other party becomes the manager. In mudhârabah, business clusters are divided according to the agreement set forth in the contract. If the business suffers a loss, then the loss is borne by the capital owner as long as the loss is not due to negligence of the manager. If the loss is caused by fraud or negligence of the pengelala, the manager must be responsible for the loss Just Antonio (2001). In the event of a loss in the mudhârabah contract, the capital owner bears the loss, the financial loss meant. Managers (mudari) bear losses in the form of loss of time and energy that has been spent but does not bring profit."

The WIF program has been run since 2019 with a focus on current activities in sheep farming, starting from breeding, milling, and marketing of animals. In 2019, the waqf funds for the WIF program amounted to IDR 
1,574,708. 757 -. The funds are used for the construction of animal drums, sheep seeds, and other equipment.

The number of livestock managed in 2019 is approximately 500 heads, either male or female. The program collaborates with the community, where the proceeds from the livestock process that shared with the breeders. The number of people involved in the program in 2019 is only six people because it is still in the early and experimental stages.

Hopefully, this program in the future will not only focus on livestock but can be integrated with agriculture because these two activities are interconnected and need each other. For example, agricultural waste becomes animal feed, and livestock waste becomes agricultural fertilizer. The business cooperation agreement is in the form of "mudaraba". Namely the collaboration between the owner of the Sinergi Foundation fund and the capital manager of the breeders to carry out certain businesses with profit sharing based on agreement in the mudloroba principle.

\section{Conclusion}

Based on the findings, productive waqaf management and financial management especially carried out by the Sinergi Foundation, shows professional, transparent and accountable. The process uses the zakat accounting standard "PSAK 109", because the Zakat and infaq funds are relatively large. So that the standard that must be used for these funds is "Statement of Financial Accounting Standards (PSAK) 109" concerning Zakat and Infaq.

Financial report (annual) audited by an independent public accountant, the results of the opinion are fair without exception (WTP). This means that the process of financial management of waqf funds has been carried out properly, transparently and accountably.

One of the community economic empowerment programs is called Waqf Integrated Agriculture (WIF). The goal is to encourage waqf-based community economic activities. The program that has been running since 2019 is focused on the field of sheep farming, from breeding, fattening to marketing. The WIF program was launched with a collaboration and profit sharing scheme between the Sinergi Foundation and breeders (mudaraba).

\section{References}

Abdul Mubaraq, (2018). The Waqf Management: Perspective in Comparison, Journal of Finance and Islamic Banking. 1 (2), http://ejournal.iainsurakarta.ac.id/in dex.php/jfib

Atan, N. A. B., \& Johari, F. B. (2017). A review on literature of Waqf for poverty alleviation between 20062016. Library Philosophy and Practice, 2017(1).

Azrai Azaimi Ambrose, A. H., Gulam Hassan, M. A., \& Hanafi, H. (2018). A proposed model for Waqf financing public goods and mixed public goods in Malaysia. International Journal of Islamic and Middle Eastern Finance and Management, 11(3), 395-415. https://doi.org/10.1108/IMEFM-012017-0001 
Chamidah, U. (2008). Pengelolaan Asset

Wakaf Tunai Pada Lembaga Keuangan Syariah (Studi Pengelolaan Wakaf Tunai Di Baitul Mal Hidayatullah Malang). Retrieved from http://etheses.uinmalang.ac.id/4261/1/04210042.pdf

Departemen Agama, 2007, Fikih Wakaf, Jakarta, Dirjen Wakaf.

Holsti, C. R. (1969). Content Analysis for The Social Science and Humanities, Canada: Departement of Political Science University of British Colombia.

Huda, N. (2012). Keuangan Publik Islam "Pendekatan Teoritis dan Sejarah." Jakarta: Kencana.

Huda, N., \& Heykal, M. (2010). Lembaga Keuangan Islam Tinjauan Teoritis dan Praktis. Jakarta: Kencana.

Kasdi, A., 2014. Peran Nadzir Dalam Pengembangan Wakaf. Jurnal Zakat $\begin{array}{llll}\text { dan } \quad \text { Wakaf. Vol } & 1 & \text { (2). }\end{array}$ https://journal.iainkudus.ac.id/index .php/Ziswaf/article/view/1483

Kasdi, Abdurrahman. (2015). Peran Waqf Produktif Dalam Pengembangan Pendidikan. Jurnal Pendidikan Islam, 3(2), 433-452. https://doi.org/10.21043/QUALITY . $\mathrm{V} 3 \mathrm{I} 2.1917$

Khoirul Anwar, Moch at al. (2020), THE ROLE OF Al-HISBAH IN IMPLEMENTATION OF BUSINESS ETHICS IN TRADITIONAL MARKETS, Amwaluna: Jurnal Ekonomi dan Keuangan Syariah, Vol. 4 No. 2 Juli 2020 Page158-175 Online ISSN : 2540-8402 | Print ISSN : 2540-8399

Mikail, S. A., Ahmad, M. A. J., \& Adekunle,
S. S. (2017). Utilisation of zakāh and Waqf fund in micro-takāful models in Malaysia: an exploratory study. ISRA International Journal of Islamic Finance, 9(1), 100-105. https://doi.org/10.1108/IJIF-072017-010

Mohamad, F., Asmak, S., Rahman, A., Marican, S., Raimi, L., Patel, A., \& Adelopo, I. (2014). The role of share Waqf in the socio-economic development of the Muslim community: The Malaysian experience"Corporate social responsibility, Waqf system and Zakat system as faith-based model for poverty reduction". Humanomics International Journal of Social Economics World Journal of Entrepreneurship Management and Sustainable

Development,30(3),227-254.

Retrieved from http://dx.doi.org/10.1108/H-122012-0025\%5Cn http://dx.doi.org/10.1108/03068290 $210413038 \% 5 \mathrm{Cn}$ http://dx.doi.org/10.1108/WJEMSD -09-2013-0052

Moh'd, I. S., Omar Mohammed, M., \& Saiti, B. (2017). The problems facing agricultural sector in Zanzibar and the prospects of Waqf-Muzar'ahsupply chain model: The case of clove industry. Humanomics, 33(2), 189-210. https://doi.org/10.1108/H02-2017-0033

Mokhtar Ismail, Hairullfazli Muhammad Som, Mohd Isa Mohd Deni, \& Muna Sulaiman. (2015). Model Operasi Wakaf Pendidikan di Malaysia. 
International Conference on Cash Waqf (ICCW), 2015(May), 215228.

Muhajir, N. (1990).Metodologi Penelitian Kualitatif, Yogyakarta : Rakesaraseh.

Muhammad Iqmal Hisham et al. (2018) Waqf Management Practices: Case Study in a Malaysian Waqf Institution, World Journal of Social Sciences, 8 (3), 1-12.

Nurul Azma et al. (2017) Exploring The Factors Of Organization Structure To Improve Waqf Management In Malaysia. International Journal of Islamic Business, 2 (2), 79-88.

Ridwan, M. (2018). Waqf Dan Pembangunan Ekonomi. ZISWAF: Jurnal Zakat Dan Waqf, 4(1), 105. https://doi.org/10.21043/ziswaf.v4i1 .3034

Sadeq, A. M. (2002). Waqf, perpetual charity and poverty alleviation. International Journal of Social Economics, 29(1-2), 135-151. https://doi.org/10.1108/0306829021 0413038

Shaikh, S. A., Ismail, A. G., \& Mohd Shafiai, M. H. (2017). Application of Waqf for social and development finance. ISRA International Journal of Islamic Finance, 9(1), 5-14. https://doi.org/10.1108/IJIF-072017-002

Siregar, D. D. (2004). Manajemen Aset: Strategi Penataan Konsep Pembanguan

Siswanto, I. E., \& Suprapto, E. (2014). Management Productive Waqf Optimalization (Case Study Tabung Waqf Indonesia). Seminar Waqf Iqlimi, Universitas Sains Malaysia,
374-395.

Surahman Maman, Nurrohman, (2020), ANALYSIS OF MAQÂSHID ALSYARI'AH ON THE APPLICATION OF THE COLLATERAL IN THE MUDHÂRABAH CONTRACT IN SHARIA FINANCIAL INSTITUTIONS, Amwaluna: Jurnal Ekonomi dan Keuangan Syariah, Vol. 4 No.2 Juli 2020 Page 276-287 Online ISSN : 2540-8402 | Print ISSN : 2540-8399

Usman, N. (2014). Pengelolaan wakaf produktif untuk kesehatan. Muaddib, 04(02), 1-20.

Van Laer, P. H. (1956). Philosophy of Science, Pittburgh :Dugnesne University. 